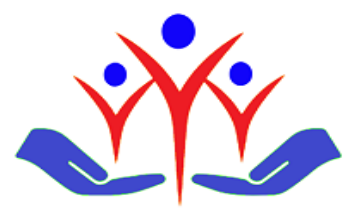

\title{
Transfer anxiety in critical care patients and their caregivers
}

\author{
Kritik bakım hastaları ve bakım verenlerinin transfer anksiyetesi
}

\section{Merve BAT TONKUS ${ }^{\mathbf{a}}$ (Dibel DOGAN ${ }^{\mathbf{b}}$, Ali Timucin ATAYOGLU ${ }^{\mathbf{c}}$}

a Department of Nursing, Faculty of Health Sciences, Istanbul Yeni Yuzyil University, Istanbul, Turkey

${ }^{\mathbf{b}}$ Department of Psychiatric Nursing, Faculty of Health Science, Istanbul Medipol University, Istanbul, Turkey

' Department of Family Medicine, International School of Medicine, Istanbul Medipol University, Istanbul, Turkey

\begin{abstract}
Introduction: Family physicians play an important role for their critically ill patients and their caregivers. Both admission and discharge in the critical care units can cause anxiety in the patients and their family caregivers. The aim of the study was to investigate transfer anxiety in patients and their caregivers due to being transferred from the intensive care unit (ICU).

Methods: This is a descriptive study that was carried out through interviewing patients and their caregivers who were hospitalized in the ICU and then transferred out due to the improvement of their general condition. The data was collected by using a Questionnaire Form and the StateTrait Anxiety Inventory (STAI).

Results: A total of 170 individuals ( 85 patients and 85 family caregivers) were involved in the study. The patient's anxiety scores were higher than their caregivers and the difference was statistically significant $(\mathrm{p}<0.001)$. The patients and their caregivers' mean anxiety scale scores after the transfer were higher in comparison with the mean scores before the transfer $(\mathrm{p}<0.001)$.

Conclusions: Transfer anxiety in patients and their caregivers due to being transferred from the ICU was confirmed. Healthcare professionals are encouraged to make the necessary adjustments to prevent transfer anxiety in critical care patients. In this process, involvement of family physicians of such patients is crucial.
\end{abstract}

Keywords: Anxiety, critical illness, psychology, intensive care units, caregivers, critical care

\section{$\ddot{O} \mathbf{z}$}

Giriş: Aile hekimleri, kritik hastaları ve onların bakım veren yakınları için önemli bir rol oynamaktadır. Kritik bakım ünitelerine hem kabul hem de taburculuk, hastalarda ve ailede kaygıya neden olabilir. Çalışmanın amacı, yoğun bakım ünitesinden (YBÜ) transfer edilmesinden dolayı hastalar ve bakım verenlerinde transfer kaygısını araştırmaktır.

Yöntem: Bu araştırma, yoğun bakım ünitesine yatırılan ve daha sonra genel durumlarının iyileşmesi nedeniyle nakledilen hastalar ve bakım verenleriyle görüşülerek yapılan tanımlayıcı bir çalışmadır. Araştırmanın verileri Anket Formu ve Durumluk Sürekli Kaygı Envanteri (STAI) kullanılarak gerçekleştirilmiştir.

Bulgular: Çalışmaya toplam 170 kişi ( 85 hasta ve 85 aile üyesi) dahil edildi. Hasta anksiyete ölçeği skorları bakım veren aile üyelerinkinden daha yüksekti ve fark istatistiksel olarak anlamlıydı $(\mathrm{p}<0.001)$. Hasta ve bakım veren yakınlarının anksiyete ölçeği ortalama skorları transfer öncesine göre transfer sonrası daha yüksekti ve fark istatistiksel olarak anlamlıydı $(\mathrm{p}<0.001)$.

Sonuç: Hasta ve yakınlarının transfer anksiyetesi deneyimledikleri onaylanmış oldu. Sağlık uzmanları, kritik bakım hastalarında transfer kaygısını önlemek için gerekli düzenlemeleri yapmaya teşvik edilmektedir. Bu süreçte, bu tür hastaların aile hekimlerinin müdahil olması çok önemlidir.

Anahtar kelimeler: Kaygı, kritik hastalık, psikoloji, yoğun bakım üniteleri, hasta bakımı verenler, yoğun bakım

\begin{tabular}{|l|l|c|l|l|}
\hline \multicolumn{1}{|c|}{ Received } & \multicolumn{1}{c|}{ Accepted } & Published Online & Corresponding Author & \multicolumn{1}{c|}{ E-mail } \\
\hline September 7, 2020 & November 10, 2020 & December 24, 2020 & Ali Timucin ATAYOGLU, MD & $\underline{\text { atatayoglu @ medipol.edu.tr }}$ \\
\hline Correspondence & $\begin{array}{l}\text { Dr. Ali Timucin ATAYOGLU, Istanbul Medipol University, Department of Family Medicine, International School } \\
\text { of Medicine, 34810, Istanbul-TURKEY }\end{array}$ \\
\hline
\end{tabular}




\section{Introduction}

Caring for critically ill patients is one of the fundamental functions of primary healthcare [1]. The integration of different healthcare teams into the operation of critical care units is of benefit to patients and family caregivers [2]. Involvement of a patient's family physician, particularly in medical decision making for critically ill patients, may be more satisfactory for the caregivers [1]. The goal is to improve quality of life for patients and family caregivers in a multidimensional or holistic manner [3].

Being a patient in the critical care areas is a traumatic event for that patient [4] and such patients may experience various psychological problems [5]. However, critical care areas may also be perceived as safe environments by some patients and their families and discharge from a familiar specialized care environment can cause a phenomenon known as 'transfer anxiety' [4-6].

The most important reasons for those individuals' transfer anxiety are the lack of adequate information about the transfer from the Intensive Care Unit (ICU) to the wards, insufficient preparation, feeling of insecurity, and experiencing an intense uncertainty [6]. There are several factors causing uncertainty, tension, insecurity, and anxiety in patients such as: changing the frequency of follow-up, changing of routines of treatment and care of the patients along with the transfer to the wards, and performing the transfer without informing the patient in advance [7,8].

It is essential to make the necessary adjustments to prevent transfer anxiety in critical care patients due to their translocation to the wards. This study was conducted as a descriptive study in order to investigate transfer anxiety in critically ill patients in the ICU and their caregivers.

\section{Methods}

\section{Ethical approval, informed consent and permissions}

The research was conducted in the ICU of Istanbul Sisli Hamidiye Etfal Training \& Research Hospital in Istanbul, between October 2015 and January 2016. The study design was approved by the Istanbul Medipol University Ethics Committee (No: 2015/443). Consent form was filled out by all participants for this study.

\section{Study design}

The study consists of ICU patients who were decided to be transferred out after showing improvement in their general condition within the specified period, patients who had been admitted in the ICU for at least 24 hours that had no communication or mental problems and their caregivers who are primary caregivers for each patient. Patients who had been admitted in the ICU for less than 24 hours and / or the ones with communication or mental problems were excluded. A total of 96 patients were upholding the inclusion criteria during the period planned for the study. The data of the study were carried out by collecting the completed questionnaire forms and the State Trait Anxiety Inventory (STAI) through talking face to face with the patients and their caregivers who were admitted in the ICU and decided to be transferred to the wards due to the improvement of their general condition.

\section{The questionnaire form for the patients}

The form consists of 10 open-ended questions such as gender, age, marital status, educational status, economic status, diagnosis, duration of stay in the ICU, the status of being informed by the health personnel about the transfer to the wards, the patients' status of approval about the transfer to the wards, and the status of their previous experience of the ICU.

\section{The questionnaire form for the patients' caregivers}

The form consists of 7 open-ended questions such as gender, age, marital status, educational status, proximity to the patient, the status of being informed by the health personnel about the transfer to the wards, the patients' status of approval about the transfer from the ICU to the wards.

\section{State-trait anxiety inventory (STAI)}

The test was developed by Spielberger et al. in 1970, and it can be administered to individuals over 14 years of age. The scale's adaption to Turkish as well as the reliability and validity works were completed by Oner and Le Compte in 1983 [9]. The State-Trait Anxiety Inventory is one of the first tests to assess both state (S) and trait (T) anxiety separately. Each type of anxiety has its own scale of 20 different questions that are scored and are rated on a 4-point scale. Anxiety absent questions represent the absence of anxiety in a statement like, "I feel secure." Anxiety present questions represent the presence of anxiety in a statement like "I feel worried." Each measure has a different rating scale. Scores range from 20 to 80, with higher scores correlating with greater anxiety. Low scores indicate a mild form of anxiety whereas median scores indicate a moderate form of anxiety and high scores indicate a severe form of anxiety. Both scales have anxiety absent and anxiety present questions [1012].

\section{Statistical analysis}

The data were analyzed with the SPSS Packet, version 20.0 (SPSS Inc., Chicago, IL, USA). The descriptive statistics of the continuous variables were given as the mean and standard deviation, in addition the descriptive statistics of categorical data were given as the frequency and percentage. The Shapiro-Wilks test was used to determine whether the data showed a normal distribution or not, in cases of the data showing abnormal distributions, the nonparametric methods were used in the statistical analysis. The Mann-Whitney U test was used to compare the two dependent groups and the Wilcoxon Signed Rank Test was used to compare the two independent groups. If there were more than two groups, the Kruskal-Wallis test was used. In the statistical analysis, the significance level was accepted as $\mathrm{p}<0.05$. 


\section{Results}

Among the total number of 96 patients who met the inclusion criteria, 85 patients with their 85 family caregivers were accepted to participate in this study. Among 170 individuals, $60 \%(n=51)$ of patients were males, $63.5 \%(n=54)$ of the patients' caregivers were females.

Table 1 shows the descriptive characteristics of the patients who were transferred from the ICU to the wards. It is seen that $35.3 \%$ of the participating patients are between 57-69 years of age, $72.9 \%$ are married, 58.8\% are primary school graduates and 57.7\% express their economic status as intermediate level. In addition to this, $21.2 \%$ of the patients received care and treatment due to cardiac issues and $20.0 \%$ due to gastrointestinal system (GIS) problems, 50.6\% stayed in the ICU for 1 day, $49.4 \%$ had previous experience in the intensive care unit, and $100 \%$ received information of their situation. $85.9 \%$ were willing to be transferred to the ward with $47.9 \%$ of these patients' identifying their primary motivation being a desire to be closer to their caregivers while the $14.1 \%$ of the patients who were not willing to be transferred identified a belief that staying in the ICU provided a safer and better care environment.

Table 2 shows the descriptive characteristics of the caregivers of the patients who were transferred from the ICU to the wards. It was determined that $54.2 \%$ of the patients' caregivers were between $31-56$ years of age, $63.5 \%$ were female, $74.1 \%$ were married and $40.0 \%$ were primary school graduates. $38.8 \%$ of the patient's caregivers were the patient child, $88.2 \%$ were informed about the condition of the patient, $69.4 \%$ were willing the patients to be transferred to the wards and while $91.5 \%$ of those caregivers' reason for this was to be closer to their patients, for $30.6 \%$ of those who were not willing the transfer the reason of was the idea of the ICU providing a safer and better care.

Table 3 shows comparison of the mean pre- and post- transfer anxiety scale scores in accordance with the descriptive characteristics of the patients' age, gender, marital status, educational status, diagnosis, length of stay in the ICU, the previous experience of staying in the ICU, and their transfer request status. The variables did not have any impact on the pre-and post-transfer anxiety scores of the patients ( $p>0.05$ ).

Table 4 shows the comparison of mean pre- and post-transfer anxiety scale scores in accordance with the descriptive characteristics of the patients' caregivers. It was determined that the variables did not have any impact on the pre-transfer anxiety scores of the patients' caregivers ( $p>0.05$ ). The descriptive characteristics of the patient's caregivers, such as the variables of marital status, educational status, the kinship status, and whether the patient being informed or not did not have an impact on the post-transfer anxiety scale scores of the patient's caregivers. However, the mean of the post-transfer anxiety scale scores were found to be higher in the caregivers who were between the ages of 44 to 56 and in the female gender, and the difference was statistically significant ( $p=0.033, p=0.022$, respectively). It was found that the mean anxiety scores of the caregivers who were willing the transfer were lower and the difference was statistically significant before and after the transfer ( $p=0.023$, $p$ $=0.043$, respectively).

Table 5 shows the comparison of the anxiety scale scores of the patients and their caregivers before and after the transfer. It was determined that the mean pre-and post-transfer anxiety scale scores of the patients were higher in comparison with the results of the caregivers and the difference was statistically significant $(\mathrm{p}<0.001, \mathrm{p}<0.001$, respectively). It was found that the mean scores of anxiety scales of the patients and their caregivers increased after the transfer and the difference was statistically significant $(p<0.001, p<0.001$, respectively). 
Table 1. The descriptive characteristics of the patients who were transferred from the ICU to the wards.

\begin{tabular}{|c|c|c|}
\hline Descriptive characteristics & $n$ & $(\%)$ \\
\hline \multicolumn{3}{|l|}{ Age } \\
\hline $18-30$ & 4 & 4.7 \\
\hline $31-43$ & 6 & 7.1 \\
\hline $44-56$ & 20 & 23.5 \\
\hline $57-69$ & 30 & 35.3 \\
\hline 70 and over & 25 & 29.4 \\
\hline \multicolumn{3}{|l|}{ Gender } \\
\hline Female & 34 & 40.0 \\
\hline Male & 51 & 60.0 \\
\hline \multicolumn{3}{|l|}{ Marital Status } \\
\hline Married & 62 & 72.9 \\
\hline Single & 6 & 7.1 \\
\hline Widowed /Divorced & 17 & 20.0 \\
\hline \multicolumn{3}{|l|}{ Educational Status } \\
\hline Illiterate & 13 & 15.3 \\
\hline Primary School & 50 & 58.8 \\
\hline High School & 14 & 16.5 \\
\hline Undergraduate and higher & 8 & 9.4 \\
\hline \multicolumn{3}{|l|}{ Socioeconomic Status } \\
\hline Lower & 3 & 3.5 \\
\hline Middle & 49 & 57.7 \\
\hline Upper & 33 & 38.8 \\
\hline \multicolumn{3}{|l|}{ Diagnosis } \\
\hline Amputation & 4 & 4.7 \\
\hline Cancer disease & 14 & 16.5 \\
\hline GIS problems & 17 & 20.0 \\
\hline Fractures & 9 & 10.6 \\
\hline Cardiac and pulmonary diseases & 18 & 21.2 \\
\hline Kidney diseases & 8 & 9.4 \\
\hline Respiratory distress & 8 & 9.4 \\
\hline Others & 7 & 8.2 \\
\hline \multicolumn{3}{|l|}{ Time spent in the ICU, in days } \\
\hline 1 & 43 & 50.6 \\
\hline 2 & 20 & 23.6 \\
\hline 3 & 7 & 8.2 \\
\hline 4 & 3 & 3.5 \\
\hline 5 & 7 & 8.2 \\
\hline 6 or more & 5 & 5.9 \\
\hline \multicolumn{3}{|l|}{ Previous admission in the ICU } \\
\hline Yes & 42 & 49.4 \\
\hline No & 43 & 50.6 \\
\hline \multicolumn{3}{|l|}{ Received information about transfer } \\
\hline Yes & 85 & 100.0 \\
\hline No & - & - \\
\hline \multicolumn{3}{|l|}{ Willing to be transferred } \\
\hline Yes & 73 & 85.9 \\
\hline No & 12 & 14.1 \\
\hline \multicolumn{3}{|l|}{ Reason for willing to be transferred $(n=73)$} \\
\hline Thinks it will be more comfortable in the ward & 13 & 17.8 \\
\hline Wants to be close to the caregivers & 35 & 47.9 \\
\hline Feeling bored in the ICU & 8 & 11.0 \\
\hline Feeling well enough & 11 & 15.1 \\
\hline Finding ICU noisy & 6 & 8.2 \\
\hline \multicolumn{3}{|l|}{ Reason for not willing to be transferred $(n=12)$} \\
\hline Thinks care is better in the ICU & 7 & 58.3 \\
\hline Thinks ICU is safer & 5 & 41.7 \\
\hline Total & 85 & 100.0 \\
\hline
\end{tabular}

Table 2. The descriptive characteristics of the caregivers of the patients who were transferred from the ICU to the wards.

\begin{tabular}{|c|c|c|}
\hline Descriptive Characteristics & $\mathbf{n}$ & $\%$ \\
\hline \multicolumn{3}{|l|}{ Age } \\
\hline $18-30$ & 16 & 18.8 \\
\hline $31-43$ & 23 & 27.1 \\
\hline $44-56$ & 23 & 27.1 \\
\hline $57-69$ & 16 & 18.8 \\
\hline 70 and over & 7 & 8.2 \\
\hline \multicolumn{3}{|l|}{ Gender } \\
\hline Female & 54 & 63.5 \\
\hline Male & 31 & 36.5 \\
\hline \multicolumn{3}{|l|}{ Marital Status } \\
\hline Married & 63 & 74.1 \\
\hline Single & 18 & 21.2 \\
\hline Widowed / Divorced & 4 & 4.7 \\
\hline \multicolumn{3}{|l|}{ Educational Status } \\
\hline Illiterate & 5 & 5.9 \\
\hline Primary School & 34 & 40.0 \\
\hline High School & 30 & 35.3 \\
\hline Undergraduate and higher & 16 & 18.8 \\
\hline \multicolumn{3}{|l|}{ Type of Kinship } \\
\hline Spouse & 26 & 30.6 \\
\hline Child & 33 & 38.8 \\
\hline Mother & 4 & 4.7 \\
\hline Sibling & 9 & 10.6 \\
\hline Other & 13 & 15.3 \\
\hline \multicolumn{3}{|l|}{ Received information about transfer } \\
\hline ( & 75 & 88.2 \\
\hline No & 10 & 11.8 \\
\hline \multicolumn{3}{|l|}{ Willing the transfer } \\
\hline Yes & 59 & 69.4 \\
\hline No & 26 & 30.6 \\
\hline \multicolumn{3}{|l|}{ Reason for willing the transfer $(n=59)$} \\
\hline $\begin{array}{r}\text { Thinks that the patient is psychologically } \\
\text { affected negatively in the ICU }\end{array}$ & 2 & 3.4 \\
\hline Wants to be close to the patient & 54 & 91.5 \\
\hline Thinks the patient is in good condition & 3 & 5.1 \\
\hline \multicolumn{3}{|l|}{ Reason for not willing the transfer $(n=26)$} \\
\hline Thinks that care is better in the ICU & 21 & 80.8 \\
\hline Thinks ICU is safer & 5 & 19.2 \\
\hline Total & 85 & 100.0 \\
\hline
\end{tabular}


Table 3. Comparison of the mean anxiety scale scores and the descriptive characteristics of the patients before and after the transfer.

\begin{tabular}{|c|c|c|c|c|}
\hline \multirow[t]{3}{*}{ Descriptive Characteristics } & \multicolumn{4}{|c|}{ Anxiety Scale Scores } \\
\hline & \multicolumn{2}{|c|}{ Before the Transfer } & \multicolumn{2}{|c|}{ After the Transfer } \\
\hline & Mean \pm SD & Test Value & Mean \pm SD & Test Value \\
\hline Age & & $\mathrm{p}$ & & $\mathrm{p}$ \\
\hline $18-30$ & $38.75 \pm 9.32$ & & $34.50 \pm 8.34$ & \\
\hline $31-43$ & $42.66 \pm 8.64$ & & $37.16 \pm 5.98$ & \\
\hline $44-56$ & $36.95 \pm 8.61$ & $6.618^{* *}$ & $32.25 \pm 6.11$ & $6.323 * *$ \\
\hline $57-69$ & $34.66 \pm 5.56$ & $\mathrm{p}=0.158$ & $31.26 \pm 5.15$ & \\
\hline 70 and over & $34.44 \pm 6.70$ & & $30.60 \pm 4.86$ & \\
\hline \multicolumn{5}{|l|}{ Gender } \\
\hline Female & $37.47 \pm 7.60$ & $718.500^{*}$ & $33.58 \pm 6.85$ & $666.000^{*}$ \\
\hline Male & $34.84 \pm 6.92$ & $\mathrm{p}=0.181$ & $30.72 \pm 4.40$ & $\mathrm{p}=0.070$ \\
\hline \multicolumn{5}{|l|}{ Marital Status } \\
\hline Married & $35.53 \pm 6.81$ & & $31.64 \pm 5.39$ & \\
\hline Single & $39.50 \pm 5.89$ & $4.033^{* *}$ & $37.66 \pm 8.14$ & 3.489 ‥ \\
\hline Widowed /Divorced & $35.94 \pm 9.20$ & $\mathrm{p}=0.133$ & $30.64 \pm 4.67$ & $\mathrm{p}=0.1 / 5$ \\
\hline \multicolumn{5}{|l|}{ Educational Status } \\
\hline Illiterate & $35.69 \pm 6.90$ & & $31.69 \pm 5.49$ & \\
\hline Primary School & $35.80 \pm 6.93$ & $2.304 * *$ & $31.82 \pm 5.72$ & $1.174 * *$ \\
\hline High School & $38.21 \pm 9.96$ & $\mathrm{p}=0.512$ & $32.64 \pm 5.54$ & $\mathrm{p}=0.759$ \\
\hline Undergraduate and higher & $32.75 \pm 3.28$ & & $31.12 \pm 6.62$ & \\
\hline \multicolumn{5}{|l|}{ Diagnosis } \\
\hline Amputation & $36.00 \pm 8.28$ & & $34.00 \pm 5.41$ & \\
\hline Cancer diseases & $37.21 \pm 7.52$ & & $32.21 \pm 5.98$ & \\
\hline GIS problems & $37.23 \pm 7.37$ & & $32.58 \pm 5.36$ & \\
\hline Fractures & $36.22 \pm 8.04$ & $11.093 * *$ & $30.55 \pm 5.27$ & $11.388^{* *}$ \\
\hline Cardiac and pulmonary diseases & $32.27 \pm 3.57$ & $\mathrm{p}=0.135$ & $29.94 \pm 6.36$ & $\mathrm{p}=0.123$ \\
\hline Kidney diseases & $32.87 \pm 5.08$ & & $29.50 \pm 3.58$ & \\
\hline Respiratory distress & $39.50 \pm 10.71$ & & $33.25 \pm 2.81$ & \\
\hline Others & $38.14 \pm 8.29$ & & $36.00 \pm 7.34$ & \\
\hline \multicolumn{5}{|l|}{ Time spent in the ICU, in days } \\
\hline 1 & $34.72 \pm 6.93$ & & $30.86 \pm 6.23$ & \\
\hline 2 & $36.60 \pm 6.17$ & 4.109 an & $32.60 \pm 4.15$ & $5.404 \%$ \\
\hline 3 or more & $37.54 \pm 8.66$ & $p=0.128$ & $33.18 \pm 5.47$ & $\mathrm{p}=0.065$ \\
\hline \multicolumn{5}{|l|}{ Willing to be transferred } \\
\hline Yes & $35.56 \pm 7.27$ & $336.000 *$ & $31.68 \pm 5.62$ & $381.500 *$ \\
\hline No & $37.91 \pm 7.29$ & $\mathrm{p}=0.196$ & $33.00 \pm 5.92$ & $\mathrm{p}=0.474$ \\
\hline \multicolumn{5}{|l|}{ Previous admission in the ICU } \\
\hline With previous experience & $34.16 \pm 5.72$ & $690.000^{*}$ & $31.09 \pm 5.41$ & $738.000^{*}$ \\
\hline Without previous experience & $37.58 \pm 8.24$ & $\mathrm{p}=0.060$ & $32.62 \pm 5.84$ & $\mathrm{p}=0.146$ \\
\hline
\end{tabular}

* Mann-Whitney U test was used for the comparison of the two dependent groups, and **Kruskal-Wallis test was used for the comparison of more than two groups. 
Table 4. Comparison of the mean anxiety scale scores and the descriptive characteristics of the patients' caregivers before and after the transfer.

\begin{tabular}{|c|c|c|c|c|}
\hline \multirow[t]{3}{*}{ Descriptive Characteristics } & \multicolumn{4}{|c|}{ Anxiety Scale Scores } \\
\hline & \multicolumn{2}{|c|}{ Before the transfer } & \multicolumn{2}{|c|}{ After the transfer } \\
\hline & Mean \pm SD & Test & Mean \pm SD & Test \\
\hline \multicolumn{5}{|l|}{ Age } \\
\hline $18-30$ & $39.81 \pm 6.50$ & & $37.12 \pm 5.99$ & \\
\hline $31-43$ & $40.69 \pm 8.17$ & & $33.43 \pm 4.39$ & \\
\hline $44-56$ & $46.73 \pm 10.93$ & $7.763^{* *}$ & $39.52 \pm 8.10$ & $10.505^{* *}$ \\
\hline $57-69$ & $38.75 \pm 5.55$ & & $36.06 \pm 6.49$ & \\
\hline 70 and over & $40.42 \pm 7.43$ & & $33.85 \pm 4.41$ & \\
\hline \multicolumn{5}{|l|}{ Gender } \\
\hline Female & $43.05 \pm 9.45$ & $659.000 *$ & $37.53 \pm 7.19$ & $586.500 *$ \\
\hline Male & $39.54 \pm 6.72$ & $\mathrm{p}=0.104$ & $34.16 \pm 4.72$ & $\mathrm{p}=0.022$ \\
\hline \multicolumn{5}{|l|}{ Marital Status } \\
\hline Married & $41.57 \pm 8.64$ & & $36.17 \pm 6.73$ & \\
\hline Single & $40.83 \pm 6.87$ & $1.717 * *$ & $36.38 \pm 5.85$ & $0.240^{* *}$ \\
\hline Widowed /Divorced & $49.25 \pm 14.79$ & & $38.00 \pm 8.86$ & $\mathrm{p}=0.887$ \\
\hline \multicolumn{5}{|l|}{ Educational Status } \\
\hline Illiterate & $38.00 \pm 4.94$ & & $34.60 \pm 3.64$ & \\
\hline Primary School & $42.70 \pm 8.15$ & $1.665^{* *}$ & $36.67 \pm 7.15$ & $0.930 * *$ \\
\hline High School & $41.30 \pm 8.79$ & $\mathrm{p}=0.645$ & $35.40 \pm 5.36$ & $\mathrm{p}=0.818$ \\
\hline Undergraduate and higher & $41.87 \pm 10.63$ & & $37.75 \pm 8.11$ & \\
\hline \multicolumn{5}{|l|}{ Received information about the transfer? } \\
\hline Yes & $41.40 \pm 8.49$ & $312.000^{*}$ & $35.89 \pm 6.15$ & $289.000^{*}$ \\
\hline No & $44.60 \pm 10.03$ & $\mathrm{p}=0.390$ & $39.40 \pm 8.98$ & $\mathrm{p}=0.239$ \\
\hline \multicolumn{5}{|l|}{ Willing the transfer } \\
\hline Yes & $40.20 \pm 7.24$ & $528.500 *$ & $35.22 \pm 5.68$ & $555.000^{*}$ \\
\hline No & $45.34 \pm 10.61$ & $\mathrm{p}=0.023$ & $38.76 \pm 7.85$ & $\mathrm{p}=0.043$ \\
\hline \multicolumn{5}{|l|}{ Kinship Status } \\
\hline Partner & $41.84 \pm 9.49$ & & $36.34 \pm 7.38$ & \\
\hline Child & $40.42 \pm 8.02$ & & $35.72 \pm 6.06$ & \\
\hline Mother & $44.75 \pm 5.50$ & $\begin{array}{l}2.771^{* * *} \\
0-0.907\end{array}$ & $37.00 \pm 5.47$ & $\begin{array}{l}1.303^{* *} \\
n-0.861\end{array}$ \\
\hline Sibling & $43.55 \pm 9.31$ & $\mathrm{p}=0.597$ & $37.00 \pm 9.15$ & $\mathrm{p}=0.861$ \\
\hline Other & $42.92 \pm 9.56$ & & $37.00 \pm 5.14$ & \\
\hline
\end{tabular}

*The Mann-Whitney U test was used for the comparison of the two dependent groups, and **Kruskal-Wallis test was used for the comparison of more than two groups.

Table 5. Comparison of the mean anxiety scale scores of the patients and their caregivers before and after the transfer.

\begin{tabular}{|c|c|c|c|c|c|c|}
\hline \multicolumn{2}{|c|}{ Anxiety Scale Scores } & \multicolumn{2}{|c|}{ Before the transfer } & \multicolumn{2}{|c|}{ After the transfer } & \multirow{2}{*}{ Test* } \\
\hline & $\mathbf{n}$ & Mean \pm SD & Test & Mean \pm SD & Test & \\
\hline Patients & 85 & $35.89 \pm 7.27$ & 2065.000 & $41.77 \pm 8.68$ & 5720.000 & $\begin{array}{c}Z=-6.353 \\
p<0.001\end{array}$ \\
\hline Patients' caregivers & 85 & $31.87 \pm 5.65$ & $\mathrm{p}<0.001$ & $36.30 \pm 6.58$ & $\mathrm{p}<0.001$ & $\begin{array}{c}Z=-6.586 \\
p<0.001\end{array}$ \\
\hline
\end{tabular}

* The Wilcoxon Signed Rank Test was used.

\section{Discussion}

In this study, it was observed that when the mean anxiety scale scores before and after the transfer were examined in accordance with the descriptive features of the patient, age, gender, marital status, educational status, diagnosis, length of stay in intensive care unit, previous experience of intensive care unit, and transfer request status did not have an impact on the pre-and post-transfer anxiety scale scores of the patients. In a study performed by Hintistan et al. (2009), it is observed that there is no significant statistical relationship between age, sex, education, marital status, occupation, diagnosis, length of stay in the intensive care unit, and the emotional states [13]. In a study performed by Aktas et al. (2015), it was also found that age, gender, marital status, and educational status did not significantly affect the total score average [14]. Being in the ICU is a very traumatic and frightening experience for the patients; the transfer from the ICU to the wards is also a process full of many unknowns for the patient.

On the other hand, when the mean anxiety scale scores before and after the transfer were examined in accordance with the descriptive features of the patients' caregivers such as age, gender, marital status, education level, information status, and proximity to the patient; these descriptive features did not have an impact on the pre-transfer anxiety scale scores of the patients' caregivers. The mean post-transfer anxiety scores were 
significantly higher in the patients' caregivers who were between the ages of 44-56 and of the female gender, while the pre-transfer and posttransfer anxiety scores of the patients' caregivers who were willing the transfer to the wards were statistically lower. Acaroglu et al. (2008) found that the anxiety level of the female caregivers of the ICU patients were higher and the marital status of the caregivers of the patients had no effect on anxiety [15]. Turedi (2011) found that there was no relationship between the caregivers of the ICU patients, gender, education level, proximity to the patient, and anxiety scores [16]. In the work of Alacacioglu (2007), it was stated that marital status and the degree of closeness to the patient had no effect on the level of depression, hopelessness, and anxiety. However, depression, hopelessness, and anxiety levels were higher in female caregivers than men [17]. In our study, most of the patients' caregivers who had higher post-transfer anxiety scores were the patients' mothers or wives. It is known that depression and anxiety disorders are more common in women in the general population [18].

In the current study, the patients' and their caregivers' mean anxiety scores after the transfer were found to be higher than the scores before the transfer and it was found that the anxiety scores of the patients were higher than the patients' caregivers. In other words, it was found that both patients and their caregivers had transfer anxiety, and that anxiety was more intense in patients in comparison to their caregivers. In the study of Gustad et al. (2008), they were reported that the patients who were transferred from the ICU to the wards experienced transfer anxiety [19]. Transfer from the critical care units to the wards affects not only the patient but also the patient's caregivers. In the study of Tel \& Tel (2009), they determined that the individual and family perceive the critical care unit as a safe, and therefore might consider the transition from the ICU to the wards negatively; it is thought that the idea of insufficient care of the patient in the wards in comparison with the ICU can cause significant transfer anxiety [20].

\section{Limitations}

This study was designed as a descriptive research in a hospital for a limited time; hence, the sample size is limited. Therefore, certain analytical statistical tests may not be able to identify every significant relationship within the data set. Basing the study in larger sample size could generate more accurate results.

Literature review is an important part of this research because it helps to identify the scope of the work that have been done so far in research area. However, prior research on the topic is remarkably limited as "transfer anxiety" is a recently identified phenomena.

\section{Conclusion}

In this study, transfer anxiety in patients and their caregivers due to being transferred from the ICU was confirmed. It was determined that both the patient and their caregivers experienced transfer anxiety and that anxiety was more intense in patients in comparison to their caregivers. If healthcare professionals fail to identify and meet such psychological conditions of patients and families transferring from critical care areas, the effects may extend far beyond.

For such patients, transfer from the critical care unit can be presented as a positive step. However, to minimize transfer anxiety, healthcare professionals should recognize the condition and approach accordingly to the emotional factors that affect patients. Therefore, during transferring from the critical care unit, it was suggested that the patients and their caregivers should be accompanied and supported in the process of adaptation throughout the transfer experience.

Primary care professionals can play an essential role in this area. Involvement of a patient's family physician may be more satisfactory for critically ill patients and their caregivers. Therefore, like palliative care, it is important to integrate primary care within the spectrum of critical healthcare services. The foundation of both critical care and primary care suggests a holistic model, which addresses the individual as a whole being consisting of all dimensions. Further studies with larger sample size, exploring the psychosocial problems, and coping strategies of the critical care patients and their family caregivers are needed.

Acknowledgments: The authors would like to express their deepest appreciation to the participants of the study. They would also like to extend their sincere thanks to Dr. Hammad Khan, MD, MPH from University of California, USA for his constructive criticism and insightful suggestions.

\section{Conflict of interest: None.}

\begin{tabular}{|l|l|l|}
\hline \multicolumn{2}{|l|}{ Author Contributions } & Author Initials \\
\hline SCD & Study Conception and Design & MBT, SD \\
\hline AD & Acquisition of Data & MBT, SD \\
\hline AID & Analysis and Interpretation of Data & MBT, SD, ATA \\
\hline DM & Drafting of Manuscript & MBT, ATA \\
\hline CR & Critical Revision & SD, ATA \\
\hline
\end{tabular}

Financial support: None. 


\section{References}

1. Huang KB, Weber U, Johnson J, Anderson N, Knies AK, Nhundu B., et al. Primary care physician involvement in shared decision making for critically ill patients and family satisfaction with care. J Am Board Fam Med 2018;31(1):64-72. https://doi.org/10.3122/jabfm.2018.01.170211

2. World Health Organization. Strengthening of palliative care as a component of comprehensive care throughout the life course. In: Sixtyseventh World Health Assembly, Geneva, 19-24 May 2014. [Access date: 1 December 2019]. Available at: http://apps.who.int/gb/ebwha/pdf files/WHA67/A67 R19-en.pdf.

3. Mercadante S, Gregoretti C, Cortegiani A. Palliative care in intensive care units: why, where, what, who, when, how. BMC Anesthesiology 2018;18(1):106. https://doi.org/10.1186/s12871-018-0574-9

4. Philbrick K, Parker A, Needham D, Karnatovskaia L. Early psychological therapy in critical illness. Semin Resp Crit Care Med 2016; 37(01):136-42. https://doi.org/10.1055/s-0035-1570367

5. Coyle MA. Transfer anxiety: preparing to leave intensive care. Intensive Crit Care Nurs 2001;17:138-43. https://doi.org/10.1054/iccn.2001.1561

6. Hupcey JE. Feeling safe: the psychosocial needs of ICU patients. J Nurs Scholarship 2000;32:361-7. https://doi.org/10.1111/j.1547$\underline{5069.2000 .00361 . x}$

7. McCairn AJ, Jones C. Does time of transfer from critical care to the general wards affect anxiety? A pragmatic prospective cohort study. Intensive Crit Care Nurs 2014;30(4):219-26. https://doi.org/10.1016/j.iccn.2013.12.004

8. Niecke A, Hartog C, Deffner T, Janssens U, Michels G. Need for psychological support in intensive care. Med Klin Intensivmed Notfmed 2020;115:135-9. https://doi.org/10.1007/s00063-018-0523-x

9. Oner N, Le Compte A. [The State-Trait Anxiety Inventory Manual] (in Turkish), Bogazici University Press, Istanbul. 1983;1-26.

10. Gros DF, Antony MM, Simms LJ, McCabe RE. Psychometric properties of the state-trait inventory for cognitive and somatic anxiety (STICSA): Comparison to the state-trait anxiety inventory (STAI). Psychol Assess 2007;19(4):369-81. https://doi.org/10.1037/1040$\underline{3590.19 .4 .369}$

11. Sydeman S. State-Trait Anxiety Inventory. In: Zeigler-Hill V., Shackelford T. (eds) Encyclopedia of personality and individual differences. Springer, Cham. 2018;1-3. https://doi.org/10.1007/978-3-319-28099-8_950-1

12. Spielberger CD. State-trait anxiety inventory. The Corsini Encyclopedia of Psychology. 2010 https://doi.org/10.1002/9780470479216.corpsy0943

13. Hintistan S, Nural N, Ozturk H. [Experiences of the patients in intensive care unit] (in Turkish). J Turk Soc Crit Care Nurs 2009;13(1):40-6. https://dergipark.org.tr/tr/download/article-file/260115

14. Aktas YY, Karabulut N, Yilmaz D, Ozkan AS. [Perception of environmental stressors by critical care patients treated in cardiovascular surgery intensive care unit] (in Turkish). Kafkas J Med Sci 2015;5(3):81-6. https://doi.org/10.5505/kjms.2015.29591

15. Acaroglu R, Kaya H, Turan Y. Levels of anxiety and ways of coping of family members of patients hospitalized in the neurosurgery intensive care unit. Neurosci 2008;13(1):41-5. https://pubmed.ncbi.nlm.nih.gov/21063284/

16. Turedi D. [The effects of the acute physiologic changes of the patients hospitalized in the intensive care unit of the psycology of the relatives] (in Turkish). Cukurova University, Faculty of Medicine, Department of Anesthesiology and Reanimation, Adana; 2011. http://libratez.cu.edu.tr/tezler/8573.pdf

17. Alacacioglu A. [Evaluation of depression, hopelessness and anxiety levels of cancer patients and their relatives] (in Turkish). Dokuz Eylul University, Faculty of Medicine, Department of Internal Medicine, Izmir; 2007. http://acikerisim.deu.edu.tr:8080/xmlui/bitstream/handle/20.500.12397/13340/224497.pdf? sequence=1\&isAllowed=y

18. Herbison CE, Allen K, Robinson M, Newnham J, Pennell, C The impact of life stress on adult depression and anxiety is dependent on gender and timing of exposure. Dev Psychopathology 2017;29(04):1443-54. https://doi.org/10.1017/s0954579417000372

19. Gustad LT, Chaboyer W, Wallis M. ICU patient's transfer anxiety: a prospective cohort study. Aust Crit Care 2008;21:181-9. https://doi.org/10.1016/j.aucc.2008.07.002

20. Tel H, Tel H. [Transfer anxiety: Common emotional experience of patients in intensive care unit and their families] (in Turkish). J Turk Soc Crit Care Nurs 2009;13(1):24-9. https://dergipark.org.tr/tr/download/article-file/260113 